\title{
Wavelet Analysis of Electrical Activities from Respiratory Muscles during Coughing and Sneezing in Anaesthetized Rabbits
}

\author{
Juliana Knociková, Ivan Poliaček, Ivo Č́p ${ }^{1}$, Helena Baráni, Ján Jakuš \\ Institute of Medical Biophysics, Jessenius Faculty of Medicine, Comenius University, Martin \\ ${ }^{1}$ Laboratory of Biomedical Engineering, University of Žilina, Slovak Republic
}

Received March 25, 2008

Accepted June 30, 2009

\begin{abstract}
Despite high behavioural similarity, some differences in the central neural control of the cough and sneeze reflexes have been suggested. The main aim of our study was to analyze and compare characteristics of electromyographic (EMG) activities of the respiratory muscles during these two behaviours.

Data were taken from eight adult rabbits under pentobarbital anaesthesia. We compared diaphragm EMG activities in tracheobronchial cough, sneeze, and quiet breathing during inspiration. Electromyograms were read from the abdominal muscles during the expiratory phases of coughing and sneezing. Due to the non-stationary character of electromyographic signals, we used wavelet analysis to determine the time-frequency distribution of energy during the behaviours.

Inspiratory durations of all above mentioned behaviours were similar. The maximum inspiratory power occurred later in sneeze than during quiet inspiration $(P<0.05)$. The total inspiratory power during sneeze was higher compared to that in cough $(P<0.05)$ and quiet inspiration $(P<0.01)$. Lower frequencies contributed to this increase significantly more in sneeze compared to cough (less than $287.5 \mathrm{~Hz}, P<0.05 ; 287.5 \mathrm{~Hz}$ up to $575 \mathrm{~Hz}, P<0.01$ ). We found similar energy distribution for coughing and quiet inspiration. Its maximum occurred at lower frequency in quiet inspiration compared to sneezing $(P<0.01)$. The abdominal burst during cough was longer than that in sneezing $(P<0.001)$.

Our results support the concept that both cough and eupnoeic inspiration are generated by similar neuronal structures. A non-specific mechanism producing expiratory activity during tracheobronchial cough and sneeze is suggested.
\end{abstract}

Defensive respiratory reflexes, neuronal control of breathing and airway reflexes, multiresolution analysis, EMG

Cough and sneeze are important defensive airway reflexes. They significantly contribute to physiological function of the respiratory system by active removal of irritants and noxious agents from the appropriate parts of the airways.

Both reflexes differ from the eupnoea mainly in active and powerful expiratory expulsions, and also in accelerated deep preparatory inspirations (Korpáš and Tomori 1979; Jakuš et al. 2004). Despite the behavioural similarities, the cough and sneeze reflexes are different kinds of behaviours. Sneeze is considered a stereotype reflex while cough presents in a variety of forms (Korpáš and Tomori 1979; Widdicombe 1995).

The preparatory inspiration of sneeze is gradational with occasional interruptions that are atypical in coughing. The expiratory airflow in sneezing is directed mainly through the nose by an elevation of the tongue (Satoh et al. 1998). The cough expiration is solely through the mouth. The differences in central controls of cough and sneeze were indicated as well (Jakuš et al. 2004).

The motor patterns of breathing, coughing, the expiration reflex, and probably other responses result from the activity of multifunctional population of the neurons in a plastic neural network(s) located in the rostral ventrolateral medulla (Shannon et al. 1996; 1998; 
Baekey et al. 2004). For example, it has been documented that the expiratory motor output in coughing is functionally related to the expiratory units of Bötzinger complex (BÖT) being situated in the rostral ventrolateral medulla (Bongianni et al. 1998).

Central neuronal patterns are transmitted to spinal motoneurons, thus forming the common inspiratory and expiratory pre-motor and motor pathways of breathing, coughing, sneezing, and other motor behaviours (Miller et al 1995; Wallois et al. 1992; Shannon et al. 1996; Iscoe 1998; Bianchi et al. 1995). Inspiratory pre-motoneurons are located within the intermedial ventral respiratory group (VRG) and dorsal respiratory group (DRG) of the medulla, whereas the expiratory pre-motoneurons occupy mainly the caudal VRG of the medulla. Inspiratory and expiratory "pump" muscles are driven through the phrenic, intercostal, and lumbar nerves.

Electrical signals propagating through the nerves and muscles carry information about the neuronal components generating the signals. Characteristics of their activities, including timing, intensity, frequency composition and other properties might be specific for individual behaviours.

Power spectral analysis derived from the Fourier transformation is a commonly used method of frequency analysis (Ackerson et al. 1983; Baráni et al. 2005). Typical characteristics of the power spectrum in respiratory motor output are the centroid frequency (Watchko et al. 1987) and high frequency oscillations (HFOs). HFOs detected from the inspiratory motor output during eupnoea are presumably generated within the respiratory central pattern generator - CPG (Cohen et al. 1979, 1987). Variances of synchronization in respiratory outputs during transition between different motor patterns were explained by the respiratory network reconfiguration and alterations in the circuitry associated with the motor pools (Marchenko and Rogers 2006).

Fourier transformation is suitable mainly for stationary signals while in contrast, respiratory motor outputs contain variable and markedly non-stationary signals especially during the airway reflexes. Hence, the wavelet transformation, which allows a multiresolution analysis, might be a more sensitive tool for analysis of non-stationary signals (Meyer 1993).

The aim of our study was to analyze and compare the frequency composition of electromyographic (EMG) activity in the diaphragm and abdominal muscles during cough, sneeze, and quiet breathing. We hypothesized that wavelet analysis would expose significant differences in the frequency characteristics of inspiratory and expiratory outputs during these behaviours. Additionally, wavelet analysis may reveal specific neuronal components involved in the generation of inspiratory and expiratory activities during cough and sneeze.

\section{Materials and Methods}

Basic experimental procedures

Experiments were performed on 8 adult rabbits (chinchilla) of both sexes $(3.83 \pm 0.52 \mathrm{~kg})$. The EMG inspiratory activities of the diaphragm (DIA) and expiratory activities of abdominal muscles (ABD) were analyzed in 55 tracheobronchial (TB) coughs and 48 sneezes. Moreover, DIA activity was determined in 45 quiet inspirations.

Anaesthesia was induced by a mixture of ketamine (Narkamon, Spofa; $25 \mathrm{mg} / \mathrm{kg}$ ) and xylazine (Rometar, Spofa; $5 \mathrm{mg} / \mathrm{kg}$ ) i.m. Subsequently, a cannula was introduced into the femoral vein and during next $2 \mathrm{~h}$ multiple small doses of pentobarbital i.v. (Vetbutal, Polfa) were used to replace the original anaesthesia (full dose of 30-40 $\mathrm{mg} / \mathrm{kg}$ ). Pentobarbital was then used to maintain a proper anaesthetic level for the remainder of the experiment. Atropine $(0.15 \mathrm{mg} / \mathrm{kg}$, i.v.) was given at the beginning of the experiment to reduce airway secretions along with hydrocortison $(2 \mathrm{mg} / \mathrm{kg}$ i.v.) used to decrease a brain swelling later during the experiment. A plastic tube was interposed into the trachea and the animal was allowed to breathe spontaneously a gas mixture of $30-50 \%$ oxygen. Arterial blood pressure (BP) was measured through a cannula placed in femoral artery. The arterial BP, End-tidal $\mathrm{CO}_{2}$ concentration $\left(\mathrm{ETCO}_{2}\right)$, respiratory rate $(\mathrm{RR})$, and body temperature were continuously monitored (body temperature was maintained within $38-40^{\circ} \mathrm{C}$ ). Samples of arterial blood were taken periodically for blood gas analysis and the metabolic acidosis control.

In order to detect the intrathoracic pressure changes a small balloon was inserted into the oesophagus (oesophageal pressure recording, EP). Animals were placed prone in a stereotaxic frame and the dorsal surface 
of medulla was exposed by an occipital craniotomy due to subsequent experiments. The surface of the brainstem was covered by warm paraffin oil.

TB cough was induced from the tracheal-bronchial region of the airways, caudal to the larynx, and the sneeze reflex from the nasal mucosa. Both $\mathrm{TB}$ and nasal mucosa were stimulated mechanically by a thin nylon fibre (maximum diameter $0.3-0.15 \mathrm{~mm}$, respectively) or by soft plastic catheter. During the trial of tracheal-bronchial stimulation a catheter was gently inserted into the trachea three times and pulled out while slowly rotating the catheter on its axis (each insertion lasting approximately $3 \mathrm{~s}$ ). For sneeze, a nylon fibre was inserted into the nostril approximately $1 \mathrm{~cm}$ deep and twisted 5 times for $5 \mathrm{~s}$. Both reflexes were characterized by coordinated inspiratory-expiratory sequences with deep inspirations (large bursts of DIA activity with a deep negative wave of EP) immediately followed by a forceful expulsive expirations (massive burst of ABD activity with strong positive swing of EP).

The animals were killed by an overdose of pentobarbital at the end of experiment. Animal care and use conformed to the guidelines accepted by the European Community, and the particular laws and regulations of the Slovak Republic.

Recording, sampling and data pre-processing

Bipolar hook fine stainless steel electrodes were introduced into the crural part of DIA and the ABD (the transversus abdominis or external oblique abdominal muscles) to record their respective electromyograms. EMGs were amplified (low noise amplifier Iso DAM8, World Precision Instruments), low pass filtered (5000 $\mathrm{Hz}$ ), digitalized by 12-bit multi-function plug-in ISA card (Dataq instruments) and sampled at $7000 \mathrm{~Hz}$. Before the wavelet analysis was performed, software filtration was done as a pass band filter for the frequency range from $100 \mathrm{~Hz}$ to $3000 \mathrm{~Hz}$.

\section{Data analysis}

The durations of inspiratory DIA ( $\left.\mathrm{T}_{\mathrm{I}}\right)$ and expiratory (during TB cough and sneeze reflex) ABD ( $\mathrm{T}_{\mathrm{E}}$ ) bursts of EMG activities were compared. We always induced repetitive sneezes in our animals (Fig. 1). Coughs appeared as both single and repetitive responses. We considered the whole cough and sneeze during their inspiratory bursts and only single bursts were analyzed and compared. Likewise, electromyographic activities were chosen during expiratory phases. Consecutively, the time and frequency domains of measured EMGs were interpreted using continuous wavelet transformation.
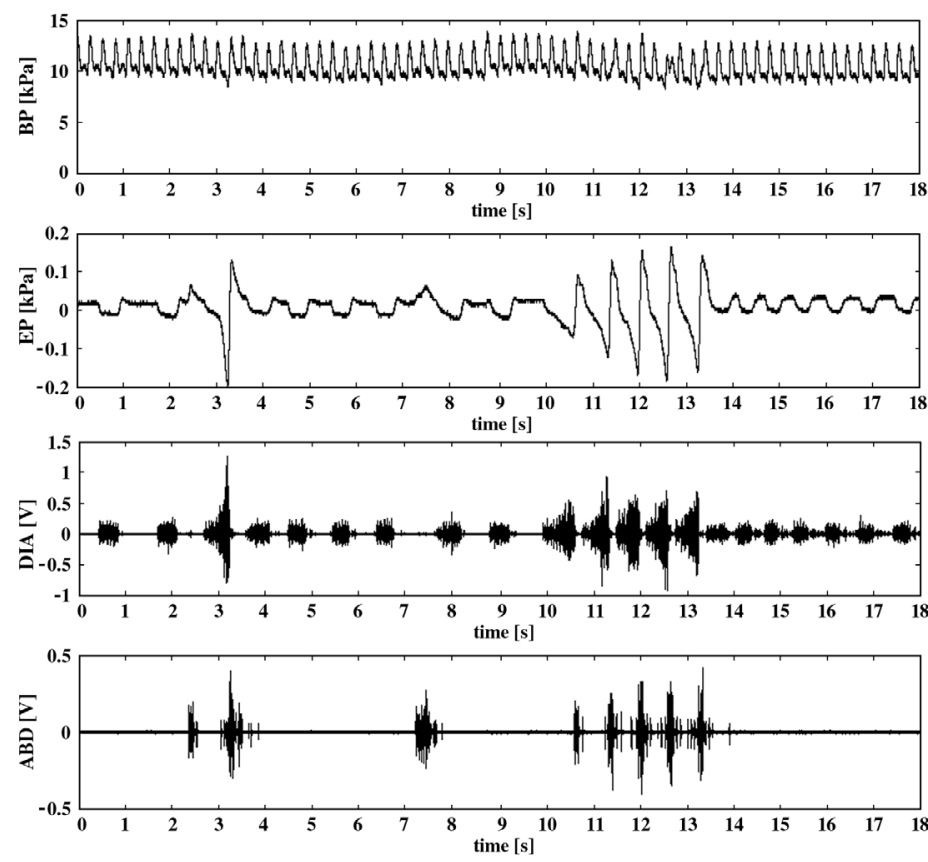

Fig. 1. Electromyographic activities during cough (single burst) and sneeze (repetitive response) induced by mechanical stimulation in pentobarbital-anaesthetized rabbit. BP - systemic arterial blood pressure, EP oesophageal pressure, DIA - electromyogram of the diaphragm, ABD - electromyogram of the abdominal muscle. 
Continuous wavelet transform decomposes the signal into the modifying versions of the mother wavelet (window function). This modification means changes of its scale (scaling) and a translation over time (Plate I, Fig. 2).

Wavelet transformation was performed using following integral

$$
W(s, \tau)=\int_{-\infty}^{\infty} x(t) \psi_{s, \tau}(t) d t=\frac{1}{\sqrt{s}} \int_{-\infty}^{\infty} x(t) \psi^{*}\left(\frac{t-\tau}{s}\right) d t
$$

where $\psi$ is the transforming function called the mother wavelet,

$\tau$ is the wavelet translation,

$s$ is the wavelet scale.

Calculated wavelet coefficients W $(s, \tau)$ are functions of the time and the wavelet scale. We used the "Morlet's wavelet" as a mother wavelet for our analysis.

It is possible to transform the scales to pseudo-frequency units $F_{a}$ (in $\mathrm{Hz}$ ):

$\mathrm{F}_{\mathrm{a}} \equiv \frac{\mathrm{F}_{\mathrm{c}}}{\mathrm{aT}_{\mathrm{S}}}$

where $a$ is a scale,

$T_{S}$ is the sampling period,

$F$ is the centre frequency of the wavelet function calculated by approximation.

Lower frequencies are represented by higher wavelet scales, higher frequencies by lower scales (Plate I, Fig. 3).

Energy stored in the burst was calculated by integration of the area under the wavelet coefficients curve. The power was expressed as a function of time and frequency. The same parameters were determined for both inspiration (the parameters of DIA activity in TB cough, sneeze, and quiet breathing), and expiration (the parameters of ABD activity in TB cough and sneeze).

Parameters of inspiration are indexed by "I", those of expiration by "E". We determined the total power of individual bursts $\left(\mathrm{P}_{\text {TотI }}\right.$ for inspiration and $\mathrm{P}_{\text {Tоте }}$ for expiration) in the scale domain, the magnitude of its maximum $\left(\mathrm{P}_{\mathrm{MI}} \mathrm{P}_{\mathrm{ME}}\right)$, and a wavelet scale at which it occurred $\left(\mathrm{P}_{\mathrm{SI}}, \mathrm{P}_{\mathrm{SE}}\right)$. In time domain, we found the moment at which maximal power occurred $\left(\mathrm{P}_{\mathrm{TI}}, \mathrm{P}_{\mathrm{TE}}\right)$.

We analyzed power in six frequency bands $\left(\mathrm{P}_{1 \mathrm{I}}-\mathrm{P}_{6 \mathrm{I}} \mathrm{P}_{1 \mathrm{E}}-\mathrm{P}_{6 \mathrm{E}}\right)$. The first band represents frequencies above 958 $\mathrm{Hz}$, the second band $575-958 \mathrm{~Hz}$, third band $287-575 \mathrm{~Hz}$, fourth $192-287 \mathrm{~Hz}$, fifth $144-192 \mathrm{~Hz}$, and the sixth band contained frequencies below $144 \mathrm{~Hz}$. The rate of contribution to the total power (ratio of the power in the frequency band to the total power of the burst) in the scale / frequency domain $\left(\mathrm{PP}_{1 \mathrm{I}}\right.$ to $\mathrm{PP}_{6 \mathrm{I}}, \mathrm{PP}_{1 \mathrm{E}}$ to $\left.\mathrm{PP}_{6 \mathrm{E}}\right)$ was also computed. Finally, we found the frequency band that contributed to total power at the highest rate $\left(\mathrm{P}_{\text {MAXI }}, \mathrm{P}_{\text {MAXE }}\right)$.

Analysis was performed by means of a self-developed computer program created in the MATLAB programming environment (HUMUSOFT, v.7.3.0.267).

\section{Statistics}

Analysis of variance (ANOVA), paired $t$-test, and Wilcoxon matched-pairs signed-ranks test were used for statistical processing of the data. In addition, we used a Chi-squared test to compare the frequency bands which contributed to total power at the highest rate $\left(\mathrm{P}_{\mathrm{MAXI}}, \mathrm{P}_{\mathrm{MAXE}}\right)$. Differences were considered significant at $P<0.05$, where $P$ is a rate of the strength of evidence against the null hypothesis with a value ranging from zero to one. Statistical calculations were performed using the GraphPad InStat (v. 3.06) software.

\section{Results}

The analyses of electromyographic activities of DIA and ABD during TB cough, sneeze, and eupnoea have shown significant differences in characteristics of their time-frequency energy distributions. A summary is presented in Table 1.

No significant difference was found in $\mathrm{T}_{\mathrm{I}}$ (duration of DIA activity) during TB coughing, sneezing, and eupnoeic inspirations $(P>0.05)$. However, the $\mathrm{T}_{\mathrm{E}}$ (ABD burst duration) in TB cough was longer than that in sneezing $\left(\mathrm{T}_{\mathrm{E}} ; 0.47314 \pm 0.11626\right.$ vs. $0.27388 \pm 0.0587$; $P<0.001)$.

The total inspiratory power $\left(\mathrm{P}_{\text {TOTI }}\right)$ and the maximum power $\left(\mathrm{P}_{\mathrm{MI}}\right)$ in the scale wavelet domain were higher in sneezing, compared to those found in TB coughs $(P<0.05 ; P<0.05)$ and quiet inspiration $(P<0.01 ; P<0.01$; Table 1$)$. The maximum power $\left(\mathrm{P}_{\mathrm{SI}}\right)$ occurred in a higher wavelet scale (lower frequencies) during quiet inspiration than in sneezing $(P<0.01)$. Also the maximum inspiratory power $\left(\mathrm{P}_{\mathrm{TI}}\right)$ occurred later in sneeze compared to that in quiet inspiration $(P<0.05)$. The inspiratory energy distributions $\left(\mathrm{P}_{\mathrm{I}}\right)$ over the frequency domain for both TB cough and the quiet inspiration were similar (Plate II, Fig. 5). However, higher 


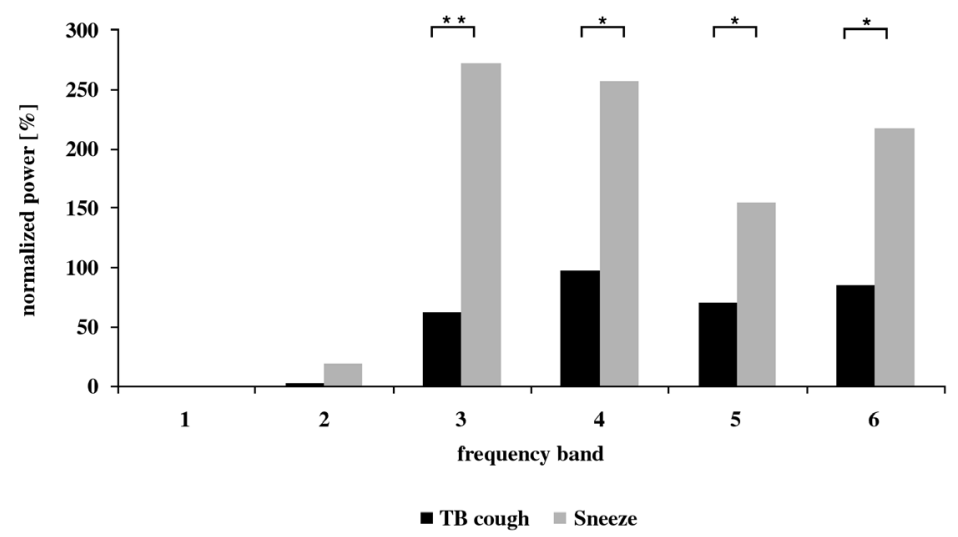

Fig. 4. Frequency composition of diaphragm activity for inspiratory period of TB cough and sneeze reflex. Inspiratory power of TB cough and sneeze is normalized to the averaged power of quiet inspiration $(100 \%)$. $* p<0.05, * * p<0.01$

Table 1. Significant differences in analyzed indicators during eupnea, TB cough, and sneeze

\begin{tabular}{|c|c|c|c|c|}
\hline Indicator & $\begin{array}{c}\text { Inspiration } \\
\text { (DIA activity) } \\
\text { EUPNOEA VS. COUGH }\end{array}$ & $\begin{array}{c}\text { Inspiration } \\
\text { (DIA activity) } \\
\text { EUPNOEA VS. SNEEZE }\end{array}$ & $\begin{array}{c}\text { Inspiration } \\
\text { (DIA activity) } \\
\text { COUGH VS. SNEEZE }\end{array}$ & $\begin{array}{c}\text { Expiration } \\
\text { (ABD activity) } \\
\text { COUGH VS. SNEEZE }\end{array}$ \\
\hline $\mathrm{P}_{\text {TOT }}$ & - & $* *$ & $*$ & - \\
\hline $\mathrm{P}_{\mathrm{M}}$ & - & $* *$ & $*$ & - \\
\hline $\mathrm{P}_{\mathrm{S}}$ & - & $* *$ & - & - \\
\hline $\mathrm{P}_{\mathrm{T}}$ & - & $*$ & - & - \\
\hline $\mathrm{P}_{1}$ & - & $* * *$ & - & - \\
\hline $\mathrm{P}_{2}$ & - & $* * *$ & - & - \\
\hline $\mathrm{P}_{3}$ & - & $* *$ & $* *$ & - \\
\hline $\mathrm{P}_{4}$ & - & $* *$ & $*$ & - \\
\hline $\mathrm{P}_{5}$ & - & ** & * & - \\
\hline $\mathrm{P}_{6}$ & - & $* *$ & $*$ & - \\
\hline $\mathrm{PP}_{1}$ & - & - & - & - \\
\hline $\mathrm{PP}_{2}$ & $*$ & $* *$ & - & - \\
\hline $\mathrm{PP}_{3}$ & - & $* *$ & - & - \\
\hline $\mathrm{PP}_{4}$ & - & - & - & - \\
\hline $\mathrm{PP}_{5}$ & - & $* *$ & - & - \\
\hline $\mathrm{PP}_{6}$ & * & * & - & - \\
\hline $\mathrm{P}_{\mathrm{MAX}}$ & $* * * *$ & $* * * *$ & $* * * *$ & ** \\
\hline
\end{tabular}

$\mathrm{P}_{\text {Tот }}$ - total power of individual bursts in the scale domain; $\mathrm{P}_{\mathrm{M}}$ - magnitude of maximum; $\mathrm{P}_{\mathrm{S}}-$ wavelet scale at which maximal power occurred; $\mathrm{P}_{\mathrm{T}}-$ time at which maximal power occured; $\mathrm{P}_{1}-\mathrm{P}_{6}-$ frequency bands; $\mathrm{PP}_{1}-\mathrm{PP}_{6}-$ frequency band power to the whole bust power contribution; $\mathrm{P}_{\mathrm{MAx}}-$ frequency band that contributed to the total power at highest rate; " - " - non-significant, $p>0.05 ; * p<0.05, * * p<0.01$, *** $p<0.001$, **** $p<0.0001$

power was found through all frequency bands $\left(\mathrm{P}_{\mathrm{r}}\right.$; Table 1) during sneezing compared to quiet inspiration $(P<0.01$ below $575 \mathrm{~Hz} ; P<0.001$ above $575 \mathrm{~Hz})$ and at lower frequencies $\left(\mathrm{P}_{3 \mathrm{I}}-\mathrm{P}_{6 \mathrm{I}}\right)$ in comparison with TB cough $\left(P<0.01\right.$ for $\mathrm{P}_{3 \mathrm{I}}$ at $(287-575) \mathrm{Hz} ; P<0.05$ for $\mathrm{P}_{4 \mathrm{I}}$ - $\mathrm{P}_{6}$ below $287 \mathrm{~Hz}$, Fig. 4).

There were similar contributions to the total power (ratio of the power in the frequency band to the total power) during the sneeze and cough reflexes. The differences were found 
in comparison to quiet inspiration, particularly between sneezing and quiet inspiration (Table 1). The second $(575-958 \mathrm{~Hz})$ frequency band contributed to the total power more $(P<0.05)$ and the sixth (below $144 \mathrm{~Hz})$ frequency band less $(P<0.05)$ in coughing compared to quiet inspiration. The second and third frequency bands $(287-958 \mathrm{~Hz})$ contributed to the total power more in sneezing compared to the quiet inspiration $(P<0.01)$. On the other hand, the fifth and sixth frequency bands (below $192 \mathrm{~Hz}$ ) contributed more to the total power of quiet inspiration compared to sneeze $(P<0.01 ; P<0.05)$.

The frequency bands contributing at the highest rate to the total power $\left(\mathrm{P}_{\mathrm{MAXI}}\right)$ were different considering analyzed groups $(P<0.0001$; Table 1$)$.

We did not find any significant difference in time-frequency energy distribution of abdominal EMGs in TB cough when compared to sneeze (Table 1), except for the frequency band contributing to the total inspiratory power at the highest rate $\left(\mathrm{P}_{\mathrm{MAXE}}\right.$ all $\left.P<0.0001\right)$. $\mathrm{P}_{\text {MAXE }}$ was mostly band 6 (below $144 \mathrm{~Hz}$ ) for sneeze and band 3 or $4(192-575) \mathrm{Hz}$ for the tracheobronchial cough.

\section{Discussion}

The main finding of our study was that there are significant differences in time-frequency distribution of inspiratory DIA activity during cough and sneeze. We found increased activity in lower frequencies in sneeze compared to that in cough. Time-frequency energy distributions of cough and eupnoeic inspirations were similar. No difference in power distribution was detected in expiratory ABD motor output during the TB coughing and sneezing.

Thus, the method of wavelet transformation was employed in an analysis of respiratory EMG outputs. Previous studies preferred the Fourier transformation to analyze frequency characteristics of inspiratory motor output during quiet breathing (Ackerson et al. 1983; O'Neal et al. 2005), the cough reflex (Baráni et al. 2005), and the aspiration reflex (Tomori et al. 1995), but the Fourier transform decomposes a signal into infinitely long harmonic components, thus losing temporal resolution. Short Time Fourier Transform (STFT) uses an equal length of the weighting function during analysis resulting in a constant time-frequency resolution making the method appropriate for stationary signals with properties that are stable over time. In the case of the wavelet transformation (unlike the Fourier transform) the length of a window in which the signal is analyzed changes dynamically. The wavelet transformation considers the properties of the signal and allows an optimal time-frequency resolution by scaling and translation of mother wavelet function. Thus, it decomposes the signal into modified versions of the mother wavelet and enables multiresolution analysis. The weighting function has limited duration and its mean value is equal to zero. Continuous wavelet transform uses scaling and time-shifting of this function called mother wavelet to obtain an optimal time and frequency localization. Wider windows at lower frequencies result in better frequency resolution, slow oscillations are better distinguishable in the frequency domain. Narrower windows allow better time resolution for fast oscillations at higher frequencies. Wavelet transformation is therefore more suitable for the analysis of non-stationary respiratory output patterns. First, the highest frequencies are detected by a narrow weighting function. Then the mother wavelet function becomes wider enabling low frequencies detection. As stated in Material and Methods, we used "Morlet's wavelet" as the mother wavelet (Goupillaud et al. 1984).

We analysed EMGs of the DIA and ABD within the range of 100-3000 Hz. Cairns and Road (1998) reported for diaphragm EMG that the power of artifacts above the frequency of $80 \mathrm{~Hz}$ was low and in turn truncated EMG below $80 \mathrm{~Hz}$. Furthermore, the most interesting frequency range for analysis of the respiratory EMG output is that above $100 \mathrm{~Hz}$ including the high frequency oscillations within the range of 105-140 Hz in rabbits (Cairns et al. 1988). 
Respiratory motor output depends on activity generated by clusters of respiratory neurons within the brainstem. The activity is then shaped, configured or reconfigured and transmitted from the medulla oblongata to the spinal cord, finally driving the "pump" and "valve" respiratory muscles (Jakuš et al. 2004). Such neural activity is specific and typical for particular respiratory behaviours. Motor nerve output is generated and patterned in order to produce an adequate muscle contraction (Fournier et al. 1988; Sieck et al. 1989). The muscle motor unit's recruitment is dependent on their contractile and fatigue properties (Cairns and Road 1998). Smaller motoneurons have a higher membrane resistance, lower rheobase, and slower axonal conduction velocities. They are recruited first during the most of motor behaviours (Sypert et al. 1981; Zajac et al. 1985). Larger motoneurons have lower input resistance, higher rheobase, and faster axonal conduction velocities. They are typically recruited later during behaviours. Our data showed higher total inspiratory drive during the sneeze reflex in rabbit compared to cough (and quiet inspiration). Also the energetic frequency distribution has shown a higher contribution of lower frequencies (bands 3-6) in inspiratory burst of sneeze. Considering that most factors that may affect the spectral EMG components, e.g. the position and type of recording electrodes, velocity of muscle action potential, firing times, temperature, common motor and pre-motor pathways, level of body temperature, $\mathrm{ETCO}_{2}$, arterial $\mathrm{BP}$, were either identical or mostly within the physiological limits in our animals. Therefore we believe that the differences found in the spectral characteristics of coughing and sneezing may originate at the brainstem and supramedullary levels, within the tentative reflex generating neuronal networks. In this respect it was also suggested that HFOs might originate within the central pattern generator of breathing (Cohen 1979; Feldman et al. 1986) and they are coherent in the medullary respiratory neurons, motoneurons, the phrenic nerve (Cohen et al. 1974), and other inspiratory-related motor nerves and muscles (Cohen et al. 1987). Their persistence in midcollicular decerebrate preparations could also establish the HFOs generator within the brainstem and/or spinal cord. HFOs are not eliminated by lesions to the pontine pneumotaxic centre and midpontine transection (Berger et al. 1978), whereas spinal hemisection results in a slight decrease in the bilateral coherence in the phrenic nerve HFOs. However, cervical transecion at $\mathrm{C} 3$ removes most of the phrenic HFOs (Bruce 1986). Various investigations suggest the importance of the medullary dorsal respiratory group in HFOs generation (Richardson and Mitchell 1982; Davies et al.1986). Experiments show that lesions 1-2 mm deep in the ventral medulla abolish HFOs in the respiratory motor output in the cat and rabbit (Romaniuk and Bruce 1991). Hence, neuronal pathways crossing the midline of the ventral medulla are crucial for HFOs generation.

The current view of the generation of the cough motor pattern is that there is a plastic common respiratory/cough generating network located within the rostral ventrolateral medulla which is able to produce both types of behaviours (Jakuš et al. 1985, 2004; Shannon et al. 1996, 2000). Our results confirm the above mentioned hypothesis of a similar mechanism for production of the cough and eupnoeic inspirations. We did not detect any significant differences in the total power and maximum power dependencies on time and scale (frequency) position. Similar observation holds for the dependencies of the power on frequency in the individual frequency bands of the DIA signal during the inspiratory period of the cough vs. eupnoeic inspiration.

Power spectral analysis has been applied on inspiratory activity of the phrenic nerve during cough and quiet breathing before (Baráni et al. 2005) with the results indicating a significant increase of power in the cough spectra not proportional to the power distribution in the spectra for quiet inspiration in anaesthetized cats. The spectral power was concentrated within the range of low frequencies in cough compared to quiet inspiration. Similar findings were reported for a dog (Yanaura et al. 1982). On the contrary, our present data on rabbits 
showed lower relative contribution of lower frequencies $\left(\mathrm{PP}_{61}\right)$ to the total power in the cough, when compared to quiet respiration. We have to emphasize that present analysis and that of Baráni et al. (2005) were done qualitatively on different types of electrical signal (DIA vs. phrenic nerve) using different filtering and methods of calculating spectral characteristics. Moreover, experiments were performed on a different species (rabbits vs. cats).

Our results showed many differences in inspiratory EMG activity during sneezing, coughing and quiet breathing. In sneezing, the maximal power was seen later in the reflex, representing a longer and more pronounced "ramp-like" character of preparatory inspiration. In a "frequency" scale the maximum was located at a higher frequency than that found for quiet inspiration. More power being produced at lower frequencies may suggest recruitment of motor units, yet only a few recruited phrenic motor units were observed in cats during the "fictive" laryngeal cough (Milano et al. 1992). Jakuš et al. (1985) reported in anaesthetized and non-paralyzed cats that identical inspiratory units were recruited both in the inspiratory phase of sneezing and the aspiration reflex, however, no recruited inspiratory neuron occurred during the inspiratory period of TB cough. Also, a low number of recruited inspiratory neurons found in cats during "fictive" coughing in the dorsal respiratory group (Gestreau et al. 1996) and the ventral respiratory group (Shannon et al. 1998, 2000). To date there is no reasonable information on the site and properties of the central pattern generator for sneezing. Behavioural and pattern differences (see introduction and Korpáš and Tomori 1979) suggest distinct CPGs for sneeze and eupnoea/cough. Nevertheless, one can not rule out the possibility that additional inspiratory drives besides the CPGs enhancing inspirations in the cough and sneeze reflexes might also affect the spectra. The degree of synchrony among the inspiratory units, which affects the spectral composition, reported for eupnoeic inspiration (Adams et al. 1989) is unknown for cough and sneeze.

The main typical component of both cough and sneeze reflexes is a forceful expiration producing the fast expiratory airflow. We saw a longer duration of ABD activity during the cough compared to that during the sneeze. Longer tetanic contraction in the cough was found in the cat as well (Tomori and Stránsky 1973). It seems that longer duration of expiratory airflow during the tracheobronchial cough may remove irritants and noxious agents from lower airways more efficiently. Moreover, the sneeze expulsions are not accompanied with bronchoconstriction as reported for cough (Tomori and Widdicombe 1969).

The time-frequency energy distribution in electromyographic activities taken from ABD was similar during the expiratory phase of both cough and sneeze. Hypothetically, this finding suggests an involvement of the same or similar mechanisms that may produce both cough and sneeze motor expulsions during expiration. For example, non-specific expiratory neurons, proposed to be active during both cough expand and sneeze (Ivančo 1973) including spontaneously active and recruited expiratory units (Jakuš et al. 1985) were observed. Also, the same types of interneurons (Price and Batsel 1970) and multiple levels of the common expiratory pre-motor (Wallois et al. 1992; Shannon et al. 1996; Jakuš et al. 2007) and motor pathways are activated during cough, sneeze, and other expiratory events (Bianchi et al. 1995; Iscoe 1998; Miller et al. 1995; Bolser et al. 2002).

Spinal mechanisms that might be involved in production of forceful expirations (and that could significantly affect the spectral characteristics in ABD activity) are not fully understood. Expiratory pre-motoneurons of the caudal VRG shows considerable activity during eupnoea, yet do not produce activation of ABD muscles. The enhancement of this activity is not proportional to the increases of ABD bursting during the "ballistic-like" expulsions in the cough or sneeze. 
In conclusion, the many similarities found in the DIA inspiratory activity during the cough reflex and eupnoea support the generally acknowledged concept of a common respiratory/cough CPG. Some differences shown between DIA activity in sneezing vs. cough/eupnoea may suggest involvement of specific neuronal structures (mechanisms) responsible for their generation or shaping. We did not find significant differences in ABD activity during tracheobronchial cough and sneeze which supports the existence of a nonspecific mechanism, capable of producing expiratory activities in response to various airway stimulations.

\section{Waveletova analýza elektrickej aktivity respiračných svalov počas kašl'a a kýchania u anestézovaných králikov}

Rozdiely v centrálnej kontrole kašl’a a kýchania sa predpokladajú aj napriek vysokej podobnosti respiračného vzoru oboch reflexov. Naším ciel'om bolo analyzovat' a porovnat' charakter elektrickej aktivity respiračných svalov u týchto dvoch reflexných dejov.

Analyzovali sme záznamy u ôsmych dospelých králikov v pentobarbitalovej anestézii. Počas inspíria sme porovnávali elektrickú aktivitu bránice pri tracheobronchiálnom kašli, kýchaní a pokojnom dýchaní. Počas exspíria boli elektromyogramy snímané z abdominálnych svalov pri kašli a kýchaní. Časovo-frekvenčnú distribúciu energie sme analyzovali prostredníctvom waveletovej transformácie vzhl'adom $\mathrm{k}$ nestacionárnemu charakteru elektromyografických signálov.

Inspírium všetkých analyzovaných prejavov trvalo približne rovnakú dobu. Maximum inspiračného výkonu sa u kýchania dosiahlo neskôr v porovnaní s pokojným inspíriom $(P<0,05)$. Celkový inspiračný výkon bol počas kýchania vyšší tak v porovnaní s kašl’om $(P<0,05)$ ako aj s pokojným inspíriom $(P<0,01)$. Na tomto zvýšení sa podiel'ali predovšetkým nižšie frekvencie u kýchania v porovnaní s kašl'om (pod $287.5 \mathrm{~Hz}, P<0,05$; $287.5 \mathrm{~Hz}$ až $575 \mathrm{~Hz}, P<0,01$ ). Detekovali sme obdobnú časovo-frekvenčnú distribúciu energie u kašl'ového aj pokojného inspíria. Maximum energie sa u pokojného inspíria zistilo pri nižších frekvenciách v porovnaní s kýchaním $(P<0.01)$. Trvanie abdominálnej aktivity počas kašl’a bolo dlhšie než počas kýchania $(P<0.001)$.

Naše výsledky podporujú predstavu, že kašlové aj eupnoické inspírium sú generované podobnými nervovými štruktúrami. Predpokladáme však nešpecifický mechanizmus generovania exspiračnej aktivity u tracheobronchiálneho kašl'a a kýchania.

\section{Acknowledgements}

We greatly thank Prof. MUDr. Juraj Korpáš Dr.Sc. for his support, helpful comments and suggestions. This study was financed from the grant VEGA 1/2274/05.

\section{References}

Ackerson LM, Bruce EN 1983: Bilaterally synchronized oscillations in human diaphragm and intercostal EMGs during spontaneous breathing. Brain Res 271: 346-348

Adams L, Datta AK, Guz A 1989: Synchronization of motor unit firing during different respiratory and postural tasks in human sternocleidomastoid muscle. J Physiol 413: 213-231

Baekey DM, Morris KF, Nuding SC Segers LS, Lindsey BG, Shannon R 2004: Ventrolateral medullary respiratory network participation in the expiration reflex in the cat. J Appl Physiol 96: 2057-2072

Baráni H, Javorka M, Jakuš J, Poliaček I, Stránsky A 2005: Spectral analysis of respiratory responses to tracheobronchial and laryngeal stimulation in cats. Acta Vet Brno 74: 191-198

Berger AJ, Herbert DA, Mitchell RA 1978: Properties of apneusis produced by reversible cold block of the rostral pons. Respir Physiol 33: 323-327

Bianchi M, Rossoni G, Sacerdote P, Panerai AE, Berti F 1995: Carbamazepine exerts anti-inflammatory effects in the rat. Eur J Pharmacol 294: 71-74

Bolser DC, Davenport PW 2002: Functional organization of the central cough generation mechanism. Pulm Pharmacol Ther 15: 221-225

Bongianni F, Mutolo D, Fontana GA, Pantaleo T 1998: Discharge patterns of Bötzinger complex neurons during cough in the cat. Am J Physiol 274: 1015-1024 
Bruce EN 1986: Significance of high-frequency oscillation as a functional index of respiratory control. In: von Euler C, Lagercrantz H (Ed.): Neurobiology of Control of Breathing. Raven Press, New York, pp. 223-229

Cairns AM, Road JD 1998: High-frequency oscillation and centroid frequency of diaphragm EMG during inspiratory loading. Respir Physiol 112: 305-313

Cohen MI, Piercey MF, Gootman PM, Wolotsky P 1974: Synaptic connections between medullary inspiratory neurons and phrenic motoneurons as revealed by cross-correlation. Brain Res 81: 319-324

Cohen MI 1979: Neurogenesis of respiratory rhythm in the mammal. Physiol Rev 59: 1105 -1173

Cohen MI, See WR, Christakos CN, Sica AL 1987: High-frequency and medium-frequency components of different inspiratory nerves discharges and their modification by various inputs. Brain Res 417: 148-152

Davies JG, Kirkwood PA, Romaniuk JR, Sears TA 1986: Effects of sagittal medullary section on high-frequency oscillation in rabbit phrenic neurogram. Respir Physiol 64: 277-287

Feldman JL 1986: Neurophysiology of breathing in mammals. In: Bloom FE (Ed.): Handbook of Physiology. The Nervous System: Intrinsic Regulatory Systems of the Brain. Bethesda, MD: Am Physiol Soc, Washington, DC, pp. 463-524

Fournier M, Sieck GC 1988: Mechanical properties of muscle units in the cat diaphragm. J Neurophysiol 59: 1055-1066

Gestreau C, Milano S, Bianchi AL, Grélot L 1996: Activity of dorsal respiratory group inspiratory neurons during laryngeal-induced fictive coughing and swallowing in decerebrate cats. Exp Brain Res 108: 247-256

Goupillaud P, Grossmann A, Morlet J 1984: Cycle-octave and related transforms in seismic signal analysis. Geoexploration 23: 85-102

Iscoe S 1998: Control of abdominal muscles. Prog Neurobiol 56: 433-506

Ivančo I 1973: Funkčne morfologická organizácia dýchacieho a kašl'ového centra (Functional - morphological organization of respiratory and cough centres). Studia Pneumol Phtiseol Cechoslov 33: 153-156

Jakuš J, Tomori Z, Stránsky A 1985: Activity of bulbar respiratory neurons during cough and other respiratory tract reflexes in cats. Physiol Bohemoslov 34: 127-136

Jakuš J, Tomori Z, Stránsky A 2004: Neuronal determinants of breathing, coughing and related motor behaviours. Wist, Martin, $335 \mathrm{p}$.

Jakuš J 2007: Central control of cough. In: Korpáš J, Paintal AS, Anand A (Ed.): Cough: From Lab to Clinic. Ane Books India, New Delhi, Chennai, Bangalore, Kolkata, pp. 117-171

Korpáš J, Tomori Z 1979: Cough and other respiratory reflexes. S Karger, Basel, München, New York, 356 p.

Marchenko V, Rogers RF 2006: Time-frequency coherence analysis of phrenic and hypoglossal activity in the decerebrate rat during eupnoea, hyperpnea, and gasping. Am J Physiol Regul Integr Comp Physiol 291: $1430-1442$

Meyer Y 1993: Wavelets: Algorithms and Applications. Society for Industrial and Applied Mathematics, Philadelphia, 133 p.

Milano S, Grélot L, Bianchi AL, Iscoe S 1992: Discharge patterns of phrenic motoneurons during fictive coughing and vomiting in decerebrate cats. J Appl Physiol 73: 1626-1636

Miller AD, Nonaka S, Siniaia MS, Jakuš J 1995: Multifunctional ventral respiratory group: bulbospinal expiratory neurons play a role in pudendal discharge during vomiting. J Auton Nerv Syst 54: 253-260

O’Neal MH, Spiegel ET, Chon KH, Solomon IC 2005: Time-frequency representation of inspiratory motor output in anaesthetized C57BL/6 mice in vivo. J Neurophysiol 93: 1762-1755

Price WM, Batsel HL 1970: Respiratory neurons participating in sneeze and in response to resistance to expiration. Exp Neurol 29: 554-570

Richardson CA, Mitchell RA 1982: Power spectral analysis of inspiratory nerve activity in the decerebrate cat. Brain Res 233: 317-336

Romaniuk JR, Bruce EN 1991: The role of midline ventral medullary structures in generation of respiratory motor high frequency oscillations. Brain Res 565: 148-153

Satoh I, Shiba K, Kobayashi N, Nakajima Y, Konno A 1998: Upper airway motor outputs during sneezing and coughing in decerebrate cats. Neurosci Res 32: 131-135

Shannon R, Baekey DM, Morris KF, Lindsey BG 1996: Brainstem respiratory networks and cough. Pulm Phamacol 9: 343-347

Shannon R, Baekey DM, Morris KF, Lindsey BG 1998: Ventrolateral medullary respiratory network and a model of cough motor pattern generation. J Appl Physiol 84: 2020-2035

Shannon R, Baekey DM, Morris KF, Li Z, Lindsey BG 2000: Functional connectivity among ventrolateral medullary respiratory neurones and responses during fictive cough in the cat. J Physiol 525: 207-224

Sieck GC, Fournier M 1989: Diaphragm motor unit recruitment during ventilatory and nonventilatory behaviours J Appl Physiol 66: 2539-2545

Sypert GW, Munson JB 1981: Basic of segmental motor control: motoneuron size or motor unit type? Neurosurgery 8: $608-621$

Tomori Z, Widdicombe JG 1969: Muscular, bronchomotor and cardiovascular reflexes elicited by the mechanical stimulation of the respiratory tract. J Physiol London 200: 25-49

Tomori Z, Stránsky A 1973: Electroneurographic and pneumotachographic analysis of the expiration reflex. Physiol Bohemoslov 22: 589-601 
Tomori Z, Fung ML, Donič V, Doničová V, St John WM 1995: Power spectral analysis of respiratory responses to pharyngeal stimulation in cats: comparisons with eupnoea and gasping. J Physiol 485: 551-559

Wallois F, Macron JM, Jounieaux V, Duron B 1992: Influence of trigeminal nasal afferents on bulbal respiratory neuronal activity. Brain Res 599: 105-116

Watchko JF, La Framboise WA, Mayock DE, Standaert TA, Woodrum DE 1987: Spectral analysis of diaphragmatic EMG during neonatal biphasic hypoxic ventilatory response. Pediatr Res 21: 238-241

Widdicombe JG 1995: Neurophysiology of the cough reflex. Eur Respir J 8: 1193-1202

Yanaura S, Kamei J, Goto K, Hosokawa T, Misawa M, Hukuhara T 1982: Analysis of efferent discharges of the phrenic nerve during the cough reflex. Jpn J Pharmacol 32: 795-801

Zajac EF, Faden JS 1985: Relationship among recruitment order, axonal conduction velocity, and muscle-unit properties of type-identified motor units in cat plantaris muscle. J Neurophysiol 53: 1303-1322 
Plate I

Knociková J. et al.: Wavelet Analysis ... pp. 387-397

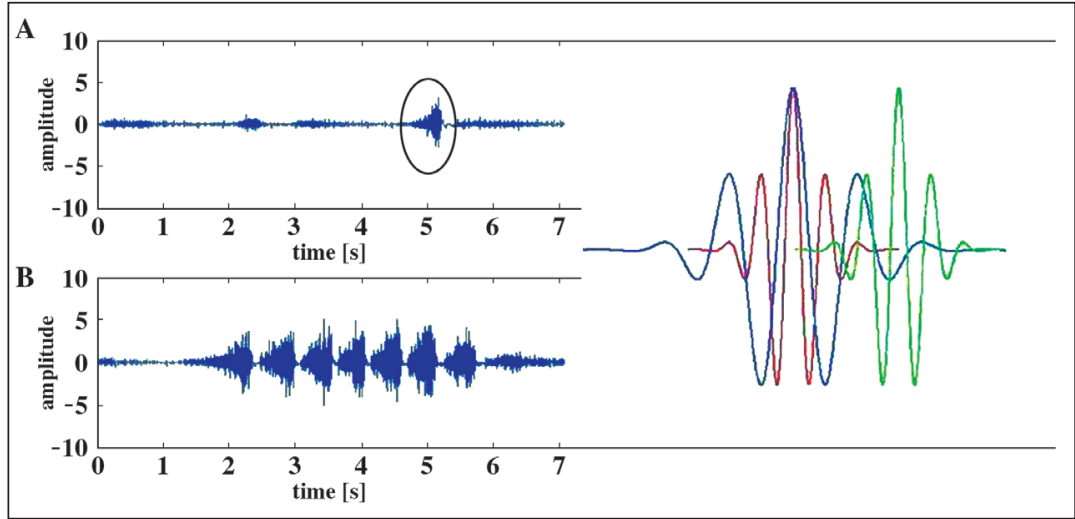

Fig. 2. Electrical activity of the diaphragm during the preparatory inspiration of the trachobronchial cough (A) and several consecutive sneeze reflexes (B) seen on the left side. "Morlet's wavelet" is depicted in its basic position (red), modified by scaling (blue) and translation (green) on the right side. Mother wavelet modifications result in its adaptation to the EMG signal properties, hence a better sensitivity is reached.

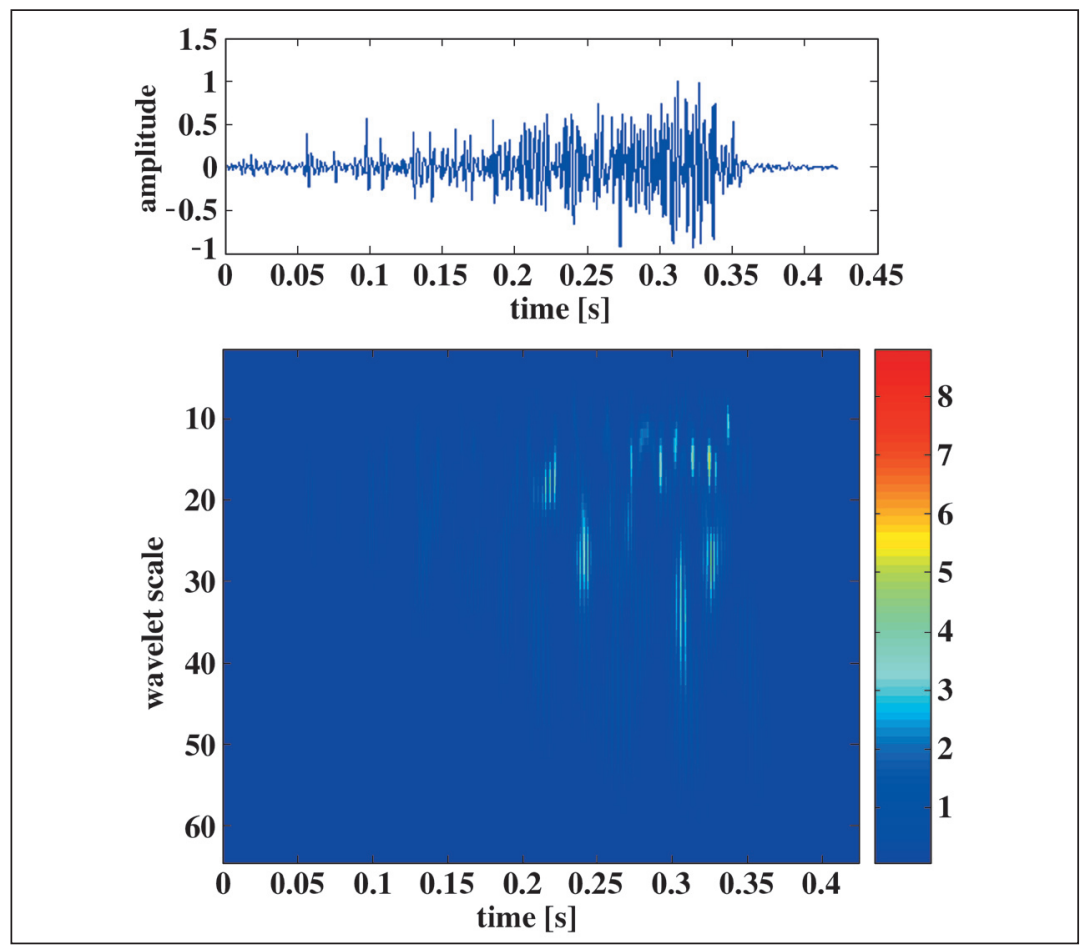

Fig. 3. Time expanded waveform and wavelet scalogram for the inspiratory phase of the tracheobronchial cough. Wavelet coefficients are function of the time and wavelet scale. Higher frequencies are expressed as lower scales, lower frequencies represent higher scales. 


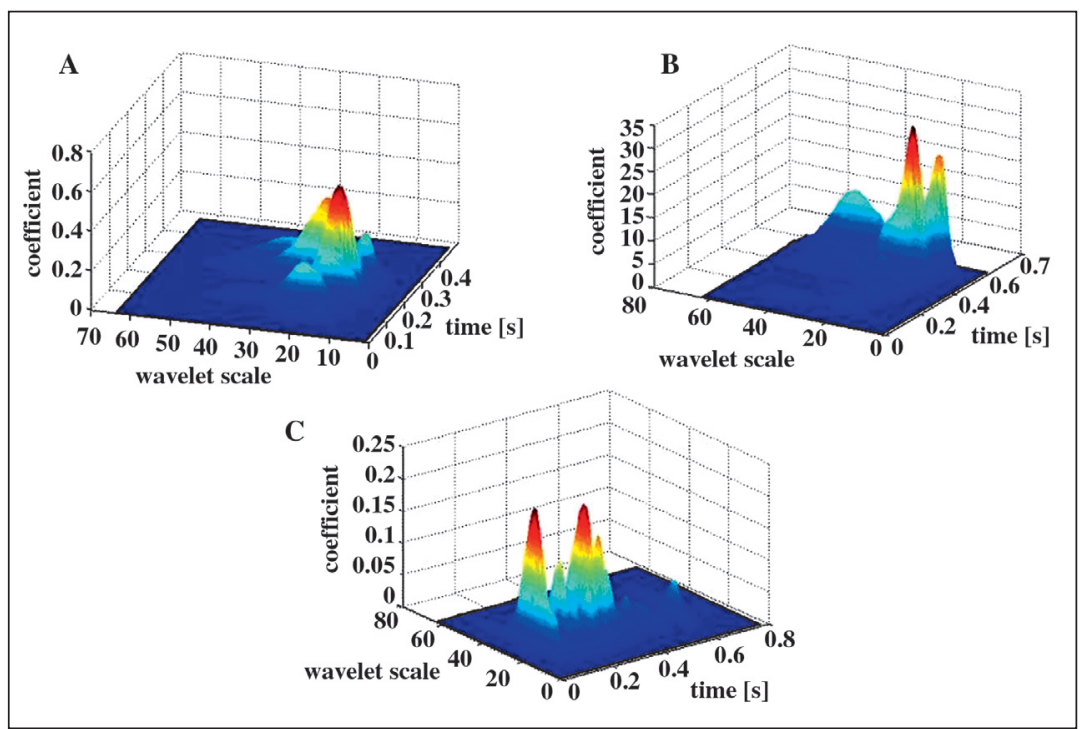

Fig. 5. 3-D wavelet scalogram of the inspiratory activity during TB cough (A), sneeze (B) and quiet breathing (C). TB cough and quiet breathing showed similar time - frequency energy distribution. Shift of the energy to the lower frequency bands is a typical sign for sneezing, compared to the TB cough. 